\title{
Contracting out of fiduciary duties
}

\section{Ernest Lim}

\begin{abstract}
A significant implication arising out of an increasingly influential view that fiduciary duties are terms expressed or implied into voluntary undertakings is that all express or implied fiduciary duties can be excluded. This article critiques this implication by advancing the argument that this implication is doctrinally unjustified and normatively questionable through an analysis of the circumstances in which directors' fiduciary duties have been contracted out under English law.
\end{abstract}

\section{Keywords}

Directors' duties, fiduciary duties, exemption

*Faculty of Law, University of Hong Kong, Hong Kong

\section{Corresponding author:}

Ernest Lim, Faculty of Law, University of Hong Kong, Hong Kong. Email: elimwk@hku.hk 


\section{Introduction}

There is extensive literature that views the law on fiduciary duties from a contractual perspective; this view is largely grounded on economic justification and is centred on American jurisprudence. ${ }^{1}$ But Justice James Edelman has attempted to characterise and rationalise fiduciary duties as contracts from an English doctrinal standpoint; he deploys case-law to show that fiduciary duties are terms expressed or implied into voluntary undertakings. ${ }^{2}$ A significant implication arises from this understanding of fiduciary duties: Edelman J claims that 'in English law all express or implied fiduciary duties can be excluded'. ${ }^{3}$ It has also been said that '(1) provisions limiting or excluding liability for ... fiduciary obligation are permissible, except, as in contract, for "core obligations"; and (2) ... fiduciary exclusion clauses are, or should be, subject to the same sort of unconscionability standard that applies in contract law'. ${ }^{4}$ Edelman $\mathrm{J}$ substantiates his claim by citing three cases whose subject matter can be broadly categorised under the heading of agency, contract, torts and trust. ${ }^{5}$ But this article seeks to show that the position is more nuanced and complex than that stated by Edelman $\mathrm{J}$ through a critical analysis of directors' fiduciary duties under English law.

This article examines the implication that all fiduciary duties can and should be excluded absent fraud and unconscionability from an English company law perspective. 
Specifically, it undertakes a close doctrinal analysis of the circumstances in which directors' fiduciary duties have been contracted out in statutory and common law through the mechanisms of authorisation, ratification and exemption. It is contended that those who characterise fiduciary duties from an essentially contractual perspective should undertake a detailed analysis of company law doctrine in order to substantiate the claim that all fiduciary duties, of which directors' duties are a prime example and therefore warrant close analysis, can and should be excluded.

The concern here is that in attempting to conceptualise and rationalise the entire law on fiduciary duties from a contractual perspective, the complexities and nuances of doctrine in other branches of law may have either been overlooked or downplayed, thus giving rise to a partial account. This is because in the context of company law, the ability to limit liability for, or contract out of, directors' fiduciary duties, through authorisation (giving advance consent to an act or transaction that would otherwise be a breach of duty) or ratification (consenting to the breach after it has taken place thereby releasing the director from liability $)^{6}$ is subject to substantial constraints, which are independent of the parties' voluntary undertaking. For example, it must be made in the best interests of the company, ${ }^{7}$ it must not be brought about by unfair or improper means, ${ }^{8}$ must not be illegal or oppressive towards the minority shareholders, ${ }^{9}$ and the majority shareholders must not appropriate themselves money, property or advantage 
which belong to the company, ${ }^{10}$ or in which the minority shareholders are entitled to participate. ${ }^{11}$ Ratification is impermissible, for example, if the breach involves misappropriation of the company's property whereas it is arguably allowed if it involves merely making an incidental profit. ${ }^{12}$

Needless to say, these constraints are of a different nature from, and extend way beyond, the 'vitiating factors' imposed in a typical private contractual arrangement such as fraud, duress, undue influence or unconscionability. These constraints are imposed regardless of the undertaking of the parties. Indeed, just as there are breaches that are non-ratifiable, ${ }^{13}$ there are those that arguably can never be authorised. These constraints could be justified on the basis of fairness to minority shareholders. Finally, other than authorisation and ratification, the other mechanism for contracting out of fiduciary duties is the direct exemption of directors from breach of duties through provisions in the company's articles; it will be argued that section 232(4) of the Companies Act 2006 (the "Act") only provides extremely limited circumstances under which this is possible. And in relation to provisions that indirectly exempt directors from liability, it will be argued that the law should require the directors voting as shareholders to act bona fide for the benefit of the company as a whole; this duty should be imposed regardless of the undertaking of the parties. 
Part I of this article summarises the doctrinal claim made by Edelman $\mathrm{J}$ as well as the claims grounded on economic justifications. The circumstances under which directors' (fiduciary) duties have been contracted out or excluded in relation to authorisation and ratification as well as exemption are critically analysed in Parts II and III, respectively. The arguments in Parts II and III have both positive and normative aspects. Positively, this article demonstrates that the limitations imposed by law with respect to authorisation, ratification and exemption require Edelman J's claim that all fiduciary duties can be excluded to be qualified. Normatively, this article argues that protection of minority shareholders provide a sound justification for these limitations, thus casting doubt on the assumption underlying the view that all fiduciary duties are terms expressed or implied into voluntary undertakings that party autonomy should be the overriding value. ${ }^{14}$ The analysis here therefore lends support to the argument that there is a vital moral dimension to fiduciary duties which is not necessarily captured in Edelman J's view that rationalises the entire law of fiduciary duties according to voluntary undertakings. ${ }^{15}$ Thus, parties not only could not exclude all fiduciary duties, but they should be barred from doing so under certain circumstances even if there is no dishonesty, unconscionability or coercion. Further, it is submitted that justifying the limitations imposed by law on ratifying and exempting liability from breaches of directors' fiduciary duties on the basis of protection of minority shareholders provides a clearer and more coherent explanation than those stated in the prevailing commentaries, 
that is, certain breaches are not ratifiable (or not authorisable) because they involve misappropriation of company's property, ${ }^{16}$ and liability can be exempted under the articles provided the directors put themselves in a position of potential as opposed to actual conflict of interest. ${ }^{17}$

\section{Excluding fiduciary duties}

Edelman J cites Bristol and West Building Society $v$ Mothew ${ }^{18}$ for the proposition that fiduciary duties are terms express or implied into voluntary undertakings. ${ }^{19} \mathrm{He}$ cites Kelly $v$ Cooper $^{20}$ (a case involving the duty of an estate agent to disclose to his principal confidential information concerning his rival principal in two separate transactions) and Citibank NA $v Q V T$ Financial $L P^{21}$ (which concerns the ability of trustees to exclude duties to act in the beneficiary's best interests) as authorities for the proposition that fiduciary duties can be excluded expressly or by implication. ${ }^{22} \mathrm{He}$ then considers whether there are any fiduciary duties that cannot be excluded. He relies on the dictum of Lord Scott in Hilton v Baker Booth and Eastwood (a firm $)^{23}$ that the solicitors could expressly exclude their duty to avoid conflict of interest although they did not do so on the facts. ${ }^{24} \mathrm{He}$ then considers the objection that certain irreducible core of trust duties cannot be excluded and argues that the objection is contrary to authority. ${ }^{25} \mathrm{He}$ states that the only limitation on the ability to contract out of fiduciary duties is the duty to act honestly because the latter is imposed by law and exists independently of contract. ${ }^{26}$ 
Edelman $\mathrm{J}$ then arrives at this conclusion: 'In summary then, in English law all express or implied fiduciary duties can be excluded' ${ }^{27}$ This conclusion is highly problematic as will be shown in the examination of directors' fiduciary duties under common law and statute; the duty to act honestly is not the only limitation. Fairness to minorities is another. Indeed, the courts have set forth limitations on the ability of shareholders to exclude directors' fiduciary duties under the statute, whether we are referring to ex ante exclusion in the form of authorisation or exemption under section $180(4)(a)^{28}$ and section $232(4)^{29}$ of the Act, respectively, or ex post exclusion in the form of ratification under section $239 .{ }^{30}$

Other than the doctrinal justifications, economic reasons have been advanced in support of the view that all fiduciary obligations can be excluded..$^{31}$ Law and economic scholars view fiduciary duties as a standard form contract comprising default rules of which participants are free to contract out. To them, fiduciary obligations perform a gap filling function by allowing terms to be implied into the agreements so that the parties do not and should not need to agree to everything in advance. Accordingly, it has been said that parties can opt out of the 'fiduciary package' ${ }^{32}$ such as through the incorporation of an exemption clause or by obtaining the principal/beneficiary's informed consent. Indeed, if fiduciary duties are viewed as default rules, or as expressed in the contract or implied in the underlying arrangement, rather than imposed by the law despite or independent of 
the parties' consent, then the beneficiaries should be able to authorise or ratify the breach; or exempt directors from liability.

However, critics argue that viewing fiduciary duties as contracts is erroneous because fiduciary obligations differ from contracts in terms of doctrine, ethical basis and purpose. ${ }^{33}$ They also argue that to characterise fiduciary duties as default rules 'strip fiduciary rules of their moral content' ${ }^{34}$ Crucially, they argue that proponents of the view of fiduciary duties as default rules fail to develop a coherent theory about the extent to which fiduciary duties can be modified. ${ }^{35}$ Indeed, although there are discussions of the means by which fiduciary duties can be contracted out ex ante and ex post, ${ }^{36}$ proponents of the view of fiduciary duties as contracts have paid insufficient attention to the mandatory limitations on these opting out mechanisms. ${ }^{37}$ These limitations undermine the claim that as long as informed consent is obtained from those to whom duties are owed, all fiduciary duties can be excluded, or liability arising from the breach of such duties can be released, except those involving dishonesty or unconscionability.

Equally important, these mandatory limitations cast doubt on the claim that such duties should be framed exclusively or primarily in terms of contract or voluntary agreement, in which party autonomy is the overriding value to the exclusion or subordination of 
other values. For example, it has been said that the view that fiduciary obligations are consensual matters because it suggests that 'they must take second place to the parties' own wishes, as expressed in their contract, or in the absence of an explicit contract, in the terms of their underlying arrangements. ${ }^{38}$ This view '.. treats the parties' own preference as paramount..., ${ }^{39}$

It will be argued below that the cases show solicitude for minority shareholders (despite the majoritarian principle remaining the overarching principle). Courts have sought to ensure that minority shareholders are treated fairly, even though it was not demonstrated that absent transaction costs, shareholders would have bargained for those terms that are protective of minority shareholders. These limitations will be demonstrated in Part II below. An important feature of these limitations is that the law is concerned about fairness to minority shareholders, a view which is not taken into account by Edelman $\mathrm{J}$ who claims that all fiduciary duties are excludable absent fraud or unconscionability. ${ }^{40}$ This is a significant distinguishing feature in company law, as compared to other branches of law, of which advocates of the view that all fiduciary duties are excludable should take into account. Indeed, it has been argued that corporate law rules 'were and still are directed primarily toward the protection of the property interests of minority shareholders'. ${ }^{41}$ Further, it has been demonstrated empirically that 'corporate governance is, to a large extent, a set of mechanisms through which outside investors 
[the non-controlling or minority shareholders] protect themselves against expropriation by the insiders', ${ }^{42}$ namely, the controlling shareholders and managers. ${ }^{43}$

\section{Authorisation and ratification ${ }^{44}$}

\section{Limitations}

Section 180(4)(a) of the Act permits members to authorise (in terms of providing advance consent to) directors' breach of duties. ${ }^{45}$ Section 239 permits members to ratify (in terms of providing consent to) breaches that have already been committed by directors, the effect of which is to release them from liability. ${ }^{46}$ Both provisions do not state the limitations on the use of these mechanisms except sections 239(3) and 239(4) which require disinterested voting. We have to turn to the common law to understand these limitations.

It is important to note that these limitations are not merely additions to the list of existing constraints to the exercise of the right to contract out of fiduciary duties, such as coercion or dishonesty. In other words, they are not merely further conditions to the right to exclude fiduciary duties. Crucially, as will be shown in this section, the law's recognition of the existence of certain wrongs that can neither be ratified nor authorised, undermines a key assumption underlying Edelman J's view that all fiduciary duties are voluntary undertakings, that is, party autonomy is and ought to be the paramount 
consideration. This is because, it is submitted, the protection of minorities is an important justification for the existence of non-ratifiable wrongs. It is submitted that Edelman J's view should account properly for the importance that the law accords to ensuring that minority shareholders are treated fairly.

In North-West Transportation Co v Beatty, ${ }^{47}$ the Privy Council held that authorisation or ratification is permissible provided that 'it is not brought about by unfair or improper means and is not illegal or fraudulent or oppressive towards those shareholders who oppose it' ${ }^{48}$ There, the claimant shareholder sued on behalf of himself and other shareholders. The defendants were the company and five shareholders. The claim was to set aside a sale made to the company by one of the directors, James Hughes Beatty, of a steamer of which he was the sole owner. On 7 February, Beatty and his supporters successfully adopted a by-law in a general meeting for the purpose of authorising the contract between Beatty and the company. ${ }^{49}$ The by-law was passed and the contract was entered into on 10 February. The court did not find that the authorisation was procured by unfair or improper means, nor was there oppressive conduct towards the minorities. The court held that the fact that the interested director Beatty voted in his capacity as shareholder to adopt the by-law did not amount to oppression of minorities. This is because the court found that the price of the steamer was based on market price and the transaction was fair. Thus, the sale was not set aside. 
The principle that interested directors are allowed to vote in a general meeting concerning transactions between themselves and the company was affirmed in a subsequent Privy Council decision in Burland $v$ Earle. ${ }^{50}$ But this principle, although applicable to authorisation, no longer applies to ratification because section 239 of the Act requires the votes of the interested director to be disregarded in a general meeting; in other words, the statutory limitation on voting only applies to ratification under section 239, not authorisation under section $180(4)(a) .{ }^{51}$

Nonetheless, Burland $v$ Earle is relevant for the purpose of this article because it reiterates the principle that neither authorisation nor ratification is permitted if 'the acts complained of are of a fraudulent character ${ }^{52}$ or beyond the powers of the company. A familiar example is where the majority are endeavoring directly or indirectly to appropriate themselves money, property or advantages which belong to the company, or in which the other shareholders are entitled to participate, as was in the case of Menier v Hooper's Telegraph Works.' ${ }^{53,54}$ In Menier, the defendant was a major shareholder of the company and had contracted with it to engage in a substantial business. The claimant, a minority shareholder, alleged that the defendant had used its votes to procure the diversion of the contract to another company and to have the company wound up. Mellish LJ held that 'the majority of shareholders cannot sell the assets of the company 
and keep the consideration, but must allow the minority to have their share of any consideration which may come to them. ${ }^{, 55}$

Accordingly, we can see from the analysis of the above cases that the law is protective of the interests of minority shareholders. This principle is further evidenced in the case of Cook v Deeks, which will be analysed below. Further, it will be argued below that this principle provides a sound justification for the distinction between ratifiable and non-ratifiable breaches, i.e. between breaches that can be consented to and those that cannot.

It should be noted, however, that fraud has a more expansive meaning than that stated in the cases above, and of course it is much broader than that understood in contract law. In Daniels $v$ Daniels ${ }^{56}$ Templeman J held that the term 'fraud' should extend to cases of self-serving negligence. He said that the fraud on the minority principle would be satisfied 'where directors use their powers intentionally or unintentionally, fraudulently or negligently in a manner which benefited themselves at the expense of the company, ${ }^{57}$ the consequence of which is that the fraudulent wrongdoing cannot be ratified. ${ }^{58}$ 
In the well-known Privy Council case of Cook $v$ Deeks, ${ }^{59}$ the court held that the company cannot ratify the wrongdoing of the directors if "the contract in question was entered into under such circumstances that the director could not retain the benefit of it for themselves, then it belonged in equity to the company and ought to have been dealt with as an asset of the company... directors holding a majority of votes would not be permitted to make a present to themselves. This would be to allow a majority to oppress the minority. ${ }^{60}$ Although the limitation imposed by the House relates to ratification, there is no reason in principle not to apply it to authorisation. There, the company had had good relationships with the Canadian Pacific Railway Company as a result of the satisfactory performance of a series of contracts. The last of the series of contracts was negotiated in the same way but the defendant directors took the contract for themselves. The claimant sued the defendants alleging that the company was entitled to the benefit of the contract. He further claimed that the ratification at the general meeting, comprising the defendants who held the majority of the shares, where it was decided that the company had no interest in the contract, was ineffective. The Privy Council ruled in the claimant's favor. The court distinguished the facts in the case and that in North-West Transportation Co v Beatty and Burland v Earle. It said that in the latter two cases, the director sold to his company property 'which was in equity as well as at law his own' ${ }^{61}$ By contrast, the contract in Cook $v$ Deeks in equity belonged to the company. 


\section{Ratifiable v non-ratifiable breach}

Commentators have argued that parties cannot consent to the breach in Cookv Deeks; in other words, the breach in Cook $v$ Deeks constitutes a non-ratifiable breach because it involves misappropriation of the company's property, in which all shareholders have a

pro-rata interest. ${ }^{62}$ By contrast, the breaches in North-West Transportation $v$ Beatty ${ }^{63}$ and Burland $v$ Earle $^{64}$ are ratifiable because no such misappropriation was involved. Professors Davies and Worthington argue that the 'existence of a set of non-ratifiable wrongs is established in the case-law... ${ }^{65}$ But they recognize that the scope of unratifiable wrongs is unclear.

It is not necessary for the purpose of this article to resolve or arrive at a conclusive view on the debate concerning the consequences of unratifiable wrongs or fraud on the minority ${ }^{66}$ given that the aim of this article is not to examine the nature, scope and effect of ratification and its relationship with the derivative action. ${ }^{67}$ What is, however, necessary and sufficient in this section is to show two things. First, the category of unratifiable wrongs does exist, even if the scope remains unsettled, because that goes to undermining the claim that all breaches of fiduciary duties can be excluded or released. And second, the cases of Cook $v$ Deeks and Regal Hastings are reconcilable on the basis of fairness to minorities, given that many commentators have argued that the fundamental reason for the uncertainty surrounding the scope of unratifiable wrongs is 
because those high authorities are irreconcilable. ${ }^{68}$ Crucially, the principle underpinning unratifiable wrongs - fairness to minorities - provides a justification for the existence of the category of unratifiable wrong; this justification helps to explain why certain breaches of fiduciary duties should not be excluded or released, in addition to explaining why only certain breaches could be excluded.

Professors Davies and Worthington distinguish a breach involving misappropriation of company's property and that which involves merely making incidental profits for which the directors are liable to account to the company. They argue that the former is nonratifiable whereas the latter is. They cite Regal Hastings in support of the latter.

Such a distinction, however, is difficult to reconcile with certain cases. For example, the influential dictum in Burland $v$ Earle stated that 'money, property or advantages which belong to the company, or in which the other shareholders are entitled to participate' cannot be ratified. It can be argued that making an incidental profit at the company's expense falls within the term 'advantage'. The House of Lords in Jubilee Cotton Mills Ltd $v$ Lewis $^{69}$ held that secret profits made either by director or promoter 'belong to' the company in equity and that he is 'bound to hand over what he has got quoeunque modo from what is really the property of the company' ${ }^{70}$ Further, Lord Wedderburn is sceptical of the distinction between Regal Hastings and Cook $v$ Deeks because, given 
that 'corporate opportunities are included within the area of assets', is there a principled reason for excluding secret profits? ${ }^{71}$

It is submitted that a more convincing reason why the making of incidental profits in Regal Hastings was ratifiable is because the minority shareholders were not prejudiced. This is consistent with the reasoning in North-West Transportation and Burland v Earle where the courts expressed solicitude for minority shareholders who might be prejudiced by the action of the majority shareholders who approved the transaction. This is also consistent with Daniels v Daniels. There, both the husband and wife were the directors and majority shareholders. The husband authorised the sale of the company's property at a gross undervalue to the wife, clearly to the detriment of the minority shareholders. Templeman J said that the husband's wrongdoing could not be ratified. Although Templeman $\mathrm{J}$ said that directors are barred from exercising their powers which benefit themselves 'at the expense of the company', he was having the minorities' interests in mind, because he arrived at that proposition by specifically relying on cases which expressly demonstrated solicitude for the minorities. ${ }^{72}$

In Regal Hastings, the directors decided that the subsidiary company could not satisfy the lessor's demand for the paid-up capital, and they also decided not to obtain additional financing for the parent company to capitalise the subsidiary. This enabled 
them to subscribe for a portion of the shares of the subsidiary. The other portion was subscribed by the parent company. Subsequently, the directors caused the shares of both parent and subsidiary companies to be sold. They made a profit. Crucially, it was not in dispute that the minority shareholders in the parent company profited from the sale as well. In any event, the outcome of the case would not have made a material difference to the welfare of the minority shareholders. It is not the case that they would be able to sell the shares at a higher price (either to the same or different purchaser) or that they could set aside the sale. This is because the purchasers' claim in Regal Hastings was not to void the transaction, but for a disgorgement of profits from the directors, the proceeds of which would be entirely pocketed by the purchasers.

To put it differently, in the words of the court in North-West Transportation, it was not demonstrated on the facts in Regal Hastings that the sale was 'illegal or fraudulent or oppressive towards those shareholders who oppose it' ${ }^{73}$ Nor, in the words of the court in Burland v Earle, was it demonstrated that 'the other shareholders are entitled to participate in' ${ }^{74}$ or benefit from, the 'money, property or advantages' ${ }^{75}$ appropriated by the directors. On the contrary, the only ones who could and did benefit from the lawsuit in Regal Hastings were the purchasers. This has to be distinguished from Cook v Deeks where the minority shareholders would benefit, albeit indirectly, from an account of profits from the defendant directors, which was the result in the case. Indeed, Professors 
Davies and Worthington observe that 'the claim in Regal Hastings was wholly unmeritorious. Recovery by the company benefited only the purchasers, who in this way received an undeserved windfall resulting, in effect, in a reduction in the price which they had freely agreed to pay. ${ }^{76}$

Accordingly, while the existence of non-ratifiable breach is supported by authorities, it is submitted that a better explanation for what constitutes ratifiable and non-ratifiable breaches lies in whether or not the interest of the minority shareholders would be unduly jeopardised. This explanation provides a better basis for reconciling Cook $v$ Deeks with Regal Hastings. Further, it is consistent with the reasoning and result in North-West Transportation, Burland v Earle and Daniels v Daniels.

Moreover, the solicitude for minorities is also evidenced in other areas of law such as the unfair prejudice remedy under section 994 of the Act. For example, Lord Hoffmann said: 'the requirement that prejudice must be suffered as a member should not be too narrowly or technically construed' ${ }^{77}$ Arden LJ held that 'the courts take a wide view of prejudice suffered by a shareholder' ${ }^{78}$ She emphasised the 'adaptability' ${ }^{79}$ of the unfair prejudice remedy, noted its "contextual' ${ }^{80}$ nature and repeatedly highlighted that it is 'flexible and open-textured'. ${ }^{81}$ Indeed, courts have held that section 994 is not limited 
to conduct unfairly prejudicial to the interests of members as members and could extend to conduct prejudicial to other interests of members, such as creditors. ${ }^{82}$

Finally, given the existence of non-ratifiable and ratifiable breaches, there is no reason in principle why the same reasoning should not be applicable to the authorisation mechanism under section 180(4)(a) of the Act. In other words, there are certain acts or transactions to which advance consent could not be given by shareholders. Indeed, Professors Davies and Worthington state that 'it would appear that the doctrine of the non-ratifiable breach restricts the scope of authorisation as much as it does that of ratification..., ${ }^{, 83}$

In sum, it should be remembered that the object of the above analysis is twofold: to demonstrate the mandatory limitations on the opting out mechanisms and to explain an underlying justification, namely, the protection of minority shareholders. These limitations and their rationales not only show that the claim that fiduciary duties can and should be contracted out as long as there is informed consent is more nuanced than that stated by Edelman J, but they undermine a key, animating assumption that party autonomy is the overriding goal. After all, the law takes the interests of minorities seriously. ${ }^{84}$ 


\section{Exemption}

\section{Direct Exemption ${ }^{85}$}

The other mechanism for contracting out of fiduciary duties is exemption. Section 232 of the Act concerns whether and the circumstances under which directors can be exempted from liability. This provision in effect transforms directors' duties into mandatory provisions. This is because section 232(1) states that 'any provision that purports to exempt a director of a company (to any extent) from any liability that would otherwise attach to him in connection with any negligence, default, breach of duty or breach of trust in relation to the company is void'. So, directors' duties cannot be waived or released in advance. Thus, qualification has to be made to a key implication arising from the claim that because directors' fiduciary duties are voluntary undertakings, the beneficiaries of those duties can release the directors from liability.

Nonetheless, some exemptions are allowed because section 232(4) states that "nothing in this section prevents a company's articles from making such provision as has previously been lawful for dealing with conflicts of interest'. What are the 'previously lawful' provisions? It should be noted that they are limited. They included provisions such as 1985 Table A, Article $85^{86}$ as well as 1948 Table A, Articles $78^{87}$ and $84{ }^{88}$ As a leading company law text observes, 'these provisions were relatively modest pragmatic provisions dealing with the reality of business relationships, situations which would fall 
primarily within section 177 rather than section 175 . That background would further support the view that there is little scope for provisions in the articles with respect to the broader conflicts governed by section $175^{,}{ }^{89}$

The issue here is whether and the extent to which companies can adopt articles, despite not exactly following those 'previously lawful' provisions, that will still be valid under section 232(1). In other words, can liability for breach of directors' duties be exempted further under section 232(4) than that prescribed by the abovementioned articles, while not contravening section 232(1)? It is submitted, for the reasons given below, that the answer should be in the negative. This issue is important for the present purpose because the answer we give to that will show that the position is more nuanced than Edelman J's claim that all fiduciary duties are excludable.

In Movitex Ltd $v$ Bulfield ${ }^{90}$, the company's articles were more extensive than Article 84 of the 1948 Table A. The articles permitted a director to be interested in the transactions in which the company was interested, and also allowed him to profit from them, if he disclosed his interest to the board and if he did not vote, although there were circumstances where he could vote and his votes would be counted. The difference between the articles in question and Article 84 was that the number of such circumstances was greater in the former than the latter. Vinelott $\mathrm{J}$ held that the articles 
were valid and did not violate section 205 of the Companies Act 1948 (now section 232 of the Act). This is because the equitable principle underlying the articles in question - a director is prohibited from placing themselves in a position in which his personal interest conflicts with his duty to the company - is a disability, not duty. Since section 205 concerned exemptions from liability, which presupposed a duty and its breach, and given that the principle underlying the articles in question were concerned with disability and not duty, it was not covered by section 205 .

Vinelott J's reasoning is objectionable for two principal reasons. First, the distinction between disability and duty has been rendered otiose because the equitable principle has been codified as a duty in section 175(1) of the Act. Second, according to the Court of Appeal in Gwembe Valley Development Co Ltd v Koshy (No 3) ${ }^{91}$, '[w] hether viewed as duties or disabilities, all such incidents are aspects of the fiduciary's primary obligation of loyalty'.92 Unsurprisingly, the court criticised the distinction as a 'needless complication'. ${ }^{93}$

It has been asserted that Vinelott $\mathrm{J}$ in effect sanctioned articles which permitted a director to place himself in a position of potential, as opposed to actual conflict of interest. ${ }^{94}$ But this seems to contradict the express and clear wording of section 175(1): "A director of a company must avoid a situation in which he has, or can have, a direct or 
indirect interest that conflicts, or possibly may conflict, with the interests of the company'. No explanation is given as to how such a contradiction can be resolved.

Birds claims that 'the general rule imposing accountability for secret profits, as well as that avoiding a transaction involving a conflict of duty and interest, would, on Vinelott J's analysis, have been excludable, so long as the director acted in good faith....[and this] is acceptable as a matter of policy' ${ }^{95}$ To Birds, Vinelott J's view in effect allows the articles to exclude all breaches of the no-conflict and no-profit rules, if the directors acted in good faith. This is problematic. Not only does Birds fail to state what the policy is, his and Vinelott J's reasoning is anathema to the prophylactic nature of fiduciary doctrine, a function of which is to 'avert breaches of non-fiduciary duties by seeking to neutralise influences likely to sway the fiduciary away from properly performing those non-fiduciary duties' ${ }^{96}$

Moreover and crucially, the interests of minority shareholders will be jeopardised. It would be difficult to alter the exemption provision in the articles. They also will not appreciate sufficiently the effect of the provision on the long-term, open-ended and unpredictable relationship among the parties. Thus, a broad exemption provision excluding liability from the breach of no-conflict and no-profit rules, other than those rendered previously lawful, should be barred. Indeed, such a clause is 'uninformed and 
speculative'. ${ }^{97}$ For example, the shareholders might give undue weight to the good relationship which they had with the directors at the time in which they agreed to the exemption provision and might discount or downplay the possibility that the directors might exercise the provision to their detriment at some point in the future. ${ }^{98}$ They might fail to appreciate the fact that the past or present (positive) relationship is not an indicator of directors' future conduct. By contrast, an exemption provision that is restricted to those previously rendered lawful will promote certainty and clarity.

In response to the argument that the company and shareholders would have agreed to such exemption provision, the Greene Committee, which recommended the introduction of the predecessor of section 232, section 205 of the Companies Act 1929, said:

It is, moreover, in our opinion, fallacious to say that shareholders must be taken to have agreed that their directors should be placed in this remarkable position. The articles are drafted on the instructions of those concerned in the formation of the company, and it is obviously a matter of great difficulty and delicacy for shareholders to attempt to alter such an article as that under consideration. ${ }^{99}$

Finally, if the company were a public company, it will be very difficult for shareholders to price such an exemption provision. This is because of two reasons articulated by Coffee. ${ }^{100}$ First, shareholders may rely on the past behaviour of directors in order to 
determine how the provision will play out but past behaviour is not a reliable predictor of future behaviour and directors may change their future behaviour in response to such a provision. Second, shareholders should not assume that directors will exploit the provision and act in an utterly self-interested manner and therefore discount the value of the shares. This is because directors are also constrained by non-legal reasons such as market forces and the preservation of reputation.

For all of the above reasons, it is submitted that companies should only adopt exemption clauses which do not depart from those previously lawful provisions. An extension of those provisions is unadvisable. Therefore, the circumstances in which directors' duties can and ought to be excluded are very limited. It is very different from the view that fiduciary duties can or should be opted out unless there is fraud, incapacity, coercion or unconscionability.

\section{Indirect exemption: Wilkinson $v$ West Coast Capital}

The above analysis concerns direct exemption. But what about indirect exemption? Suppose there is a provision in the articles which restricts the company's business to a certain scope but permits the company to diversify its business only if consent is obtained from $66 \%$ of the shareholders. According to Warren $\mathrm{J}$ in Wilkinson $v$ West 
Coast Capital, ${ }^{101}$ if an opportunity to acquire another company (of a different business) comes up, the shareholders, who are also directors, can refuse to consent to the acquisition, even if the board is of the view that the company (i.e. the acquirer) will benefit from it. Thus, the directors, voting as shareholders, who refuse the consent, can exploit the opportunity for themselves. It is irrelevant whether the information on the opportunity to acquire was obtained by them in the course of acting as directors. According to Warren J, they will be exempted from liability for breach of fiduciary duty as directors to the company. ${ }^{102}$ This is because the directors, when voting as shareholders, are under no duty to use their votes to approve the acquisition. ${ }^{103}$ This is an example of an indirect exemption provision, or a provision, though not on its face exempting directors from liability, has the effect of doing so. What this means is that the directors, who are also shareholders, can exercise their votes as they please, even if by doing so, the company's interest will be harmed. ${ }^{104}$ This is because shareholders, unlike directors, do not owe fiduciary duties to the company.

Warren J's reasoning is unsatisfactory. Even where directors vote as members, they can exercise their votes with impunity in order to harm the company's interests, or although not intending to do so, the effect of which is to do so. ${ }^{105}$ And directors cannot be held accountable for exploiting the opportunity and making a profit, even if it is a clear case of conflict of interest. It is a clear case because, although the scope of the target's 
business is different from the acquirer's, the board of the acquirer has determined that it is in the latter's interest to make the acquisition. And yet, the directors are permitted to exploit the opportunity. Thus, the interests of the directors conflict with the company's.

Similarly, Warren J held that the same principles apply to provisions in the shareholders' agreement in question. In that case, Clause 5 of the agreement provided 'unless the shareholders holding in excess of $65 \%$ of the issued shares otherwise agree in writing the shareholders shall exercise their power in relation to the company so as to ensure that... the company does not acquire or invest in another company or business or incorporate any subsidiary'. Warren J held that because the shareholders did not agree to the acquisition, the directors, who were also the shareholders, were thus free to exploit the opportunity and were exempted from liability. ${ }^{106}$

So, there is first instance authority to support the proposition that fiduciary duties can be contracted out through such indirect exemption provisions in the articles or shareholders' agreement. This appears to lend support to Edelman J's claim. But the more important and interesting issue for our purpose here is whether there ought to be any limitation on such indirect exemption provision that is independent of the undertaking of the parties, and which is in addition to fraud, unconscionability or bad faith. This issue is crucial because it could undermine the claim that all fiduciary duties 
should be excludable unless there is fraud, unconscionability or bad faith. It will be argued below that where directors vote as shareholders, they ought to be constrained by the duty to act in good faith for the benefit of the company as a whole. In other words, it will be argued that there is no convincing reason in principle to preclude the extension of the duty imposed on shareholders to act bona fide for the company's benefit as a whole in the context of alteration of articles ${ }^{107}$ to the situation involving indirect exemption, as shown by the facts in Wilkinson $v$ West Coast Capital.

It is important to note that the requirement that the power to alter the articles must be exercised bona fide for the company's benefit as a whole is justifiable on the basis of the protection of minority shareholders' interests. This justification also underpins the law concerning ratification and authorisation as well as the distinction between ratifiable and non-ratifiable breaches, as discussed in Part I. Lindley MR in Allen v Gold Reefs of West Africa ${ }^{108}$ held that because the power to alter the articles is a power enabling the majority to bind the minorities, ${ }^{109}$ that power must not be exercised to the detriment of minority shareholders' interests. Although he formulated the rules in the language of 'for the benefit of the company as a whole', he had the protection of minority shareholders in mind. Lindley MR said: 
Wide, however, as the language of s. 50 is, the power conferred by it must, like all other powers, be exercised subject to those general principles of law and equity which are applicable to all powers conferred on majorities and enabling them to bind minorities. It must be exercised, not only in the manner required by law, but also bona fide for the benefit of the company as a whole, and it must not be exceeded.

So, protection of minorities' interests is a normative justification underlying the rule in Allen $v$ Gold Reefs. Concern for minorities' interests was also evident in two other cases. In Brown v British Abrasive Wheel Company $\mathrm{Co},{ }^{110}$ the court said:

The question therefore is whether the enforcement of the proposed alteration on the minority is within the ordinary principles of justice...I find it very difficult to follow how it can be just and equitable that a majority, on failing to purchase the shares of a minority by agreement, can take power to do so compulsorily. ${ }^{11}$

And in Greenhalgh v Arderne Cinemas, ${ }^{112}$ the court held that a special resolution in that case "would be liable to be impeached if the effect of it were to discriminate between the majority shareholders and the minority shareholders, so as to give the former an advantage of which the latter were deprived'. ${ }^{113}$ 
One objection to extending the duty to act bona fide for the company's benefit to the context of indirect exemption is that although shareholders are subject to the duty of good faith, a distinction has to be drawn between non-fiduciaries and fiduciaries. Professors Nolan and Conaglen argue that the duty of good faith only requires the nonfiduciary, the controlling shareholders in our case, not to intentionally harm the interest of the minority shareholders. ${ }^{114}$ They are not subject to the requirement not to exercise their powers that will thwart the furtherance of the beneficiary's or principal's interests. By contrast, fiduciaries, such as directors, are subject to this requirement. Therefore, Professors Nolan and Conaglen argue that it is easy to reconcile the proposition that shareholders can vote in their self-interest with that of shareholders being under a duty to act in good faith when they alter the articles, as stated in Allen v Gold Reefs of West Africa Ltd. ${ }^{115}$ According to them, the reason is that good faith in this context merely bars the shareholders from voting in a way that intentionally harms the interests of the other shareholders, except to the extent that the harm is a necessary consequence of the shareholders lawfully acting in their self-interest. ${ }^{116}$

But there are two difficulties with their understanding of the duty of good faith to which shareholders are subject. First, for our purpose, the duty of good faith - understood as not intentionally harming another party's interest - lacks any bite. It will be virtually impossible, in the example discussed above, to prove that the shareholders deliberately 
did not consent to the acquisition in order to inflict harm on the minority shareholders. Absent unusual circumstances, what can be proven is that they acted out of self-interests so that they can exploit the opportunity and be exempted from liability as directors. Good faith, in the attenuated sense articulated by Professors Nolan and Conaglen, appears to be simply the flip side of bad faith. The duty to act in good faith is merely the duty not to act in bad faith. Not only does it lack any bite, but such a duty does not add anything new to the existing requirement that non-fiduciaries must not act in bad faith. It does not pose a credible limitation on indirect exemption provisions.

The other more serious difficulty is that contrary to the claim made by Professors Nolan and Conaglen, the duty imposed on shareholders to act 'bona fide for the benefit of the company as whole' when they alter the articles extends beyond not intentionally inflicting harm on the other shareholders. In Brown v British Abrasive Wheel $\mathrm{Co}^{117}$ for example, a company urgently required capital injection. $98 \%$ of the shareholders agreed to provide the capital on condition that they could acquire the remaining shares. But the remaining shareholders rejected this offer. So, the majority proposed to alter the articles by adding a provision to the effect that if $90 \%$ of the shareholders require a shareholder to transfer his shares, the latter is obliged to do so. The good faith of the majority was never an issue. They did not intend to harm the interests of the minority. The alteration was motivated by the company's interests. Still, the court held that the result of the 
alteration, which allowed the majority to expropriate the minority, was not for the benefit of the company as a whole but only for the majority's benefit. This clearly implies it is necessary but insufficient that the majority shareholders did not act in bad faith in Professors Nolan and Conaglen's sense, i.e. they did not intentionally harm the interests of the other shareholders. Something more is required: benefit to the company has to be demonstrated, and the proposed article has to be narrowly drafted to tailor to the purpose for which the change was made; otherwise the proposed article will be invalidated even if bad faith is absent. Moreover, in Sidebottom v Kershaw, Leese \& Co $L t d,{ }^{118}$ the court held that a proposed resolution to add a provision to the articles to enable the company to require any shareholder who competed with the company to sell his shares at fair value to the company was valid because it benefited the company.

Professors Nolan and Conaglen may distinguish the above cases on the basis that they deal with compulsory transfer of shares. In other types of situations, they could cite Shuttleworth v Cox Bros $L t d^{119}$ as authority for the proposition that the court will defer to the members and will not intervene unless bad faith (i.e. deliberate harm) is shown. But the deference has not been uncritical. As Professors Davies and Worthington observe, there is an element of 'objective control' in the bona fide test - 'the decision [has to] be one which a reasonable shareholder could have considered to be in the interests of the company'. ${ }^{120}$ This is a far cry from the mere requirement, stated by 
Professors Nolan and Conaglen, not to intentionally inflict harm on minority shareholders.

Given that benefit to the company has to be demonstrated in order to satisfy the bona fide test, the issue here is whether this test should be applied to circumstances not involving the alteration of the company's articles. That is, in the above example on indirect exemption provision in the articles or shareholders' agreement, should the law require the directors, voting as shareholders, to act bona fide for the benefit of the company as a whole? It is not an answer to say that this will conflict with the proposition that shareholders can vote as they please and can do so without regard to the adverse effect it would have on the company. This is because if this answer were correct, then the law in the very first place should not have imposed on shareholders the duty to act bona fide for the benefit of the company as a whole when they alter the articles.

The real issue here is whether there is any principled and coherent justification for restricting the bona fide requirement only to the situation involving alteration of articles, especially given the fact that interests of the company and especially minority shareholders will clearly be harmed in the example discussed above. To recap the example, the board decided that taking up the opportunity to pursue the acquisition, 
which came to the knowledge of the directors acting in the course of directorship, is in the company's interest. But there is a provision in either the company's articles, or the shareholders' agreement, which stipulates that consent from a certain percentage of the shareholders is required for this acquisition. But the same directors, voting as shareholders, refused to consent to the acquisition so that they could exploit it themselves. In this situation, the company suffers twice. First, the losses it would have suffered as a result of being prohibited from making use of the opportunity. Second, it cannot sue the directors for breach of fiduciary duties for exploiting the opportunity and making a profit; this is because the directors are exempted from liability. And needless to say, the minority shareholders also suffer.

It is submitted that given that shareholders' agreement can amount to a special resolution altering the articles, ${ }^{121}$ the indirect exemption provision in the shareholders' agreement has to be subject to the same requirement that shareholders have to act bona fide for the company's benefit as a whole when they seek to alter the articles. In relation to the indirect exemption provision in the articles, one way of analysing this issue is to ask ourselves what if there were initially no such provision in the articles, but the directors, acting as shareholders, decided to alter the articles in order to introduce a provision in the articles which precludes the company from undertaking the acquisition, so that they could exploit the opportunity for themselves? In this situation, would not 
the shareholders be subject to the requirement to act bona fide for the benefit of the company as a whole? What material difference does it make to the analysis whether the indirect exemption provision happened to be in the articles in the first place or whether it was subsequently included upon alteration? Unless a compelling justification is given for what makes shareholders' alteration of articles unique so as to confine the imposition of the bona fide duty only to that situation, it is submitted that in the specific example concerning indirect exemption provision in the articles described above, the directors, when voting as shareholders, should be subject to the same requirement to act bona fide for the company's benefit as a whole.

Moreover, while Australian case law has recognised shareholders' right to vote for their benefit, it has extended the requirement that shareholders must vote bona fide for the benefit of the company as a whole beyond the situation of alteration of articles, and imposed a general requirement that shareholders must exercise their voting powers for the company's benefit as a whole. ${ }^{122}$

The practical effect of imposing this duty would not lead to the denial of the right of the majority shareholders to pursue the opportunity. This is because the bona fide duty requires that only if the court is satisfied that no reasonable shareholder could have thought that the decision was in the company's interest, then the decision will be 
invalidated. This is not an easy burden. To illustrate, let us return to our earlier example. Suppose that the company was in need of financing and the only financing available to the company was from the majority. The majority agreed to finance the company only if they were allowed to pursue the acquisition. In this situation, the majority, who were also the directors, might have performed a cost benefit analysis and arrived at the genuinely held belief that a reasonable shareholder could have considered that obtaining the financing was in the company's interest, rather than voting to allow the company to pursue the acquisition. Thus, consent was withheld by the majority, and the majority took up the opportunity instead. In this case, it is submitted that the shareholders' decision would be upheld by the court.

In sum, in the context of indirect exemption, that is, where directors who are also the controlling shareholders exercise their power to vote in order to allow themselves to exploit opportunities which they encounter in their course of their directorship, the effect of which is to exempt themselves from breaches of fiduciary duties, the law ought to constrain their exercise of voting power by requiring them to act bona fide for the benefit of the company. It is submitted that this requirement undermines the claim that fiduciary duties ought to be excludable as long as there is no fraud, coercion or unconscionability. Further, because the normative justification underlying this 
restriction is protection of minorities' interest, it is highly questionable whether party autonomy ought to be the paramount or overriding consideration.

\section{Conclusion}

This article critiques the claim that all fiduciary duties are excludable absent dishonesty, coercion or unconscionability. It shows that this claim is doctrinally unjustified and normatively questionable. In relation to authorisation and ratification, the law will not and should not permit ex ante or ex post consent to such acts if the minorities are oppressed. With regards to direct exemption provisions, the law should not permit a broad exemption excluding liability other than those rendered previously unlawful because, among other reasons, the minority shareholders have inadequate and unequal information on the existence and scope of the provisions. And as for indirect exemption provisions, the law should impose a requirement that directors when they vote as shareholders have to exercise their votes for the benefit of the company as a whole in order to ensure that minorities are treated fairly.

Finally, by critiquing a key implication arising from the claim that fiduciary duties are terms expressed or implied into voluntary undertakings from an English company law doctrinal perspective, this article hopes to caution against the propensity to produce 'overarching' or 'grand' ${ }^{123}$ theories that purport to rationalise, unify and subsume an 
area of law, practice or phenomenon, that is so complex and multi-faceted, such as fiduciary duties in this instance, under the rubric of a monolithic and uniform concept. While 'overarching' theories can provide an elegant explanation of the law, this may ride roughshod over the nuances, complexities and ambiguities in other aspects of legal doctrines.

\section{Acknowledgements}

I would like to thank Lusina Ho, John Lowry and the two anonymous referees for helpful comments. All errors remain my own.

\section{Declaration of Conflicting Interest}

The author declares that there are no conflicts of interest. 


\section{${ }^{1}$ Notes}

. For examples of the contractarian view, see Easterbrook and Fischel (1993); Cheffins (1991); Butler and Ribstein (1990); Langbein (2004); Duggan (2010: 275).

2. Edelman (2010), cited with approval in F \& C Alternative Investments (Holdings) Ltd v Barthelemy (No 2) [2012] 3 WLR $10(\mathrm{Ch})$ (per Sales J) at para. 225; Justice Edelman states: 'The theory which is closest to the argument in this paper is the "contractarian" theory which sees fiduciary duties as contractual': see fn. 173 in his article. But given that Justice Edelman's article is a piece of doctrinal analysis of the case law, he clarifies that his article 'does not rely upon the economic justifications usually accompanied by the proponents of the theory'. See also Edelman (2013). The argument that fiduciary duties are best understood on the basis of voluntary undertakings has been criticised in Conaglen (2013). See also Rotman (2005: 96-100). Although the purpose of Smith's article is not to critique Edelman's argument, Smith's thesis is distinctly different from Edelman's in that he argues that the no-conflict rule is imposed by law to ensure subjective loyalty, rather than, as claimed by Edelman, based on a construction of an objective undertaking: Smith (2013). For another definition of fiduciary duty that is different from Edelman's, see Frankel (2011: 6-41, 235-239).

${ }^{3}$. Edelman (2010: 298).

${ }^{4}$. Duggan (2010: 293).

5. Kelly v Cooper [1993] AC 205 and Hilton v Barker Booth \& Eastwood (a firm) [2005] 1 WLR 567 overlap with agency, torts (negligence) and contract. Citibank NA \& Anor v QVT Financial LP [2007] 1 CLC 113 is concerned with liability of trustees.

${ }^{6}$. The other meaning of ratification is the validation of transaction by the company. This article is not concerned with this aspect of ratification.

7. Madoff Securities International Ltd v Raven [2011] EWHC 3102 at [123].

${ }^{8}$. North-West Transportation Co v Beatty (1887) 12 App Cas 589 at 594.

9. Ibid.

${ }^{10}$. Burland v Earle [1902] AC 83 at 93.

${ }^{11}$. Menier v Hooper's Telegraph Works (1874) 9 Ch App 350 at 354. 
12. Cook v Deeks [1916] 1 AC 554; see for example, Davies and Worthington (2012: 624); Hannigan (2009: 247). See also Edwards v Halliwell [1950] 2 All ER 1064 where the court laid down four categories of unratifiable wrongs, i.e. ultra vires and illegal acts, acts requiring the sanction of a special majority, acts infringing the personal rights of shareholders and acts that constitute a fraud on the minority. For a detailed analysis, see Wedderburn (1957) and Wedderburn (1958).

${ }^{13}$. Davies and Worthington (2012); Hannigan (2009). See the analysis below in n. 62-84 and accompanying text.

${ }^{14}$. In addition to the protection of minority shareholders, the law also protects creditors' interests by not permitting shareholders to authorise or ratify directors' wrongdoing when the company is insolvent or approaching insolvency: West Mercia Safetywear Ltd v Dodd (1988) 4 BCC 30 at 33 per Dillon LJ.

${ }^{15}$. See for example, Finn (1989A); Finn (1989B); FitzGibbon (1999: 341-352). Contractarians, however, may argue that the fair treatment of minorities is not a moral consideration because it is not about pursuing justice but efficiency and expediency; if minorities are not protected, they will not invest in companies and this will impede the ability of companies, especially publicly listed ones, to raise capital. But this argument fails to account for the fact that the courts themselves invoke notions of fairness and justice. See for example Brown v British Abrasive Wheel Company Co [1919] 1 Ch 290 and Allen v Gold Reefs of West Africa Ltd [1900] 1 Ch 656, discussed below in n. 107-109 and accompanying text.

${ }^{16}$. See for example, Davies and Worthington (2012).

${ }^{17}$ Ibid. at 629. See the analysis below in n. 94-100 and accompanying text.

${ }^{18}$. [1998] Ch 1.

${ }^{19}$. Edelman (2010: 300).

${ }^{20}$. Kelly, above n. 5 .

21. Citibank, above n. 5.

${ }^{22}$. Edelman (2010: 302-303).

${ }^{23}$. Hilton, above n. 5.

${ }^{24}$. Edelman (2010: 302-303). 
${ }^{25}$. Ibid. at $303-304$.

${ }^{26}$. Ibid. at 304-305.

${ }^{27}$. Ibid. at 306 .

${ }^{28}$. See generally Morse (2007: 177-178); Mortimore (2009: 232-234).

${ }^{29}$. Morse (2007: 214-215); Mortimore (2009: 451-452).

${ }^{30}$. Morse (2007: 219-220); Mortimore (2009: 457-462).

${ }^{31}$. Above n. 1.

${ }^{32}$. Duggan (2010: 279).

33. See for example, FitzGibbon (1999); DeMott (1988); Frankel (1995); Leslie (2005).

${ }^{34}$. Leslie (2005: 70).

35. Ibid.

${ }^{36}$. For examples of the US view, see Ayres and Gertner (1989); Butler and Ribstein (1990).

37. For an example of the UK and Australian view, see Whincop (1997) who devotes only one page to analysing the limitations.

${ }^{38}$. Duggan (2010: 275).

39. Ibid.

${ }^{40}$. For an endorsement of this view but from a US perspective, see Chander (2003) and the US cases examined therein. But see Flannigan (2014) who argues that the courts were wrong to have held that the majority has a duty not to oppress the minority.

${ }^{41}$. Berle (1958: 1212).

${ }^{42}$. La Porta et al. (2000: 4). See also La Porta et al. (2008) for their response to critics. 
${ }^{43}$. It might be said however that the protection of minority shareholders is consistent with the view of the contractarian scholars who argue that fiduciary duties are contracts in the form of either default rules (if they can be opted out) or hypothetical bargains (if they cannot be opted out). But the purpose of this article is not to challenge contractarian theory at large. Rather, it is to critique Edelman J's argument through a doctrinal analysis of the circumstances under which directors' fiduciary duties can and should be contracted out. Thus, the issue of whether contractarian theory can account for the protection of minority shareholders is outside the scope of, and does not detract from the thesis advanced in, this paper.

44. See generally, Payne (1999); Cranston (1992); Partridge (1987); Worthington (2000); Hirt (2004); Koh (2005); Hannigan (2000). Given the purpose and scope of this paper, the issue concerning the relationship between ratification and derivative action is not discussed; for the latest discussion, see Riley (2014). In examining the mechanisms of authorisation and ratification here, it is not necessary for the purpose of this article to distinguish the nature of transaction and the nature of voting by shareholders. The issue is partially resolved in s. 239 of the Act as only disinterested members are permitted to ratify. But the problem still remains as to whether there are any unratifiable breaches; this is discussed below in 62-84 and accompanying text. On authorisation, s. 180(4)(a) does not specify whether only disinterested members can authorise (unlike s. 239). Thus, commentators state that the voting limitation applies only to s. 239, not s. 180(4)(a): see below n. 47. But the issue here is whether there are any transactions or acts that cannot be authorised, just as there are certain breaches that cannot be ratified. In other words, whether the right to authorise under s. 180(4)(a) is subject to certain common law limitations, like the right to ratify under s. 239 . This article answers in the affirmative.

45. Section 180(4)(a) states: 'The general duties-have effect subject to any rule of law enabling the company to give authority, specifically or generally, for anything to be done (or omitted) by the directors, or any of them, that would otherwise be a breach of duty...'

46. Section 239(1) states: 'This section applies to the ratification by a company of conduct by a director amounting to negligence, default, breach of duty or breach of trust in relation to the company'. Section 239(2) states: 'The decision of the company to ratify such conduct must be made by resolution of the members of the company'.

${ }^{47}$ (1887) 12 App Cas 589; Smith (2012: 393).

${ }^{48}$. Ibid. at 594 per Sir Richard Baggallay who delivered the judgment for the court (emphasis added).

49. According to Professors Sealy and Worthington, this case has been widely understood as 'one of the leading authorities for the principle that a general meeting may ratify an act of the directors which is voidable as an irregular 
exercise of their power...' But Sealy and Worthington disagree with this view and argue that '[a] close examination of the facts, and of the arguments of counsel, however, suggest that the whole point of the proposed "bye-law" was to put the proposal that the company should buy the ship before the members for them to decide': Sealy and Worthington (2010: 241). This implies that this case is also authority for the proposition that authorisation (and not just ratification) of the directors' act, which would otherwise be a breach of duty, is permissible if it was not brought about by unfair or improper means and if it was not illegal or fraudulent or oppressive towards those shareholders who oppose it. See also Smith (2012: 393).

${ }^{50} \cdot[1902]$ AC 83 .

${ }^{51}$. Davies and Worthington (2012: 247): 'That statutory voting limitation applies only to ratification and, therefore, it might seem that there may be tactical advantage in seeking prior shareholder authorization rather than relying on subsequent ratification'.

${ }^{52}$. But the nature, scope and consequences of fraud remain unsettled: see Riley (2014); Payne (1999: 614-5).

${ }^{53}$. (1874) 9 Ch App 350.

${ }^{54}$. Burland, above n. 50 at 93 per Lord Davey who delivered the judgment for the court (emphasis added).

${ }^{55}$. Menier, above n. 11 at 354.

${ }^{56}$. [1978] Ch 406.

${ }^{57}$. Ibid. at 414. But see Pavlides v Jensen [1956] Ch 565 where it was held that negligence in itself is not sufficient.

58. But see Prudential Assurance Co Ltd v Newman Industries Ltd (No 2) [1981] 1 Ch 257 at 307 where Vinelott J said that fraudulent wrongdoing is ratifiable if the wrongdoers 'did not control the company' and the majority 'does not have an interest which conflicts with that of the company'. But Vinelott J's view contradicts well-established authorities and has been criticised by commentators: see for example, Wedderburn (1981). For a more a sympathetic view, see Riley (2014: 589-590). Vinelott $\mathrm{J}$ was of the view that fraudulent breaches require a disinterested vote but not for nonfraudulent breaches. However, this is no longer true because s. 239 requires disinterested votes.

59. [1916] 1 AC 554.

${ }^{60}$. Ibid. at 564 per Lord Buckmaster LC who delivered the judgment of the court (emphasis added). 
${ }^{61}$. Ibid. at 563.

${ }^{62}$. Davies and Worthington (2012).

${ }^{63}$. (1887) 12 App Cas 589.

${ }^{64}$. [1902] AC 83.

${ }^{65}$. Davies and Worthington (2012: 626).

66. The key issue in the debate is whether in connection with the derivative action, the law should move from a transaction based approach (in which we look at the character of the wrongdoing) to a voting based approach (in which all wrongdoing can be ratified insofar as there is disinterested voting): see Riley (2014).

${ }^{67}$. By contrast, see for example, the articles by Payne (1999), Hannigan (2000) and Riley (2014).

${ }^{68}$. See for example, Payne (1999: 614-615) and Riley (2014); see also Wedderburn (1957); Wedderburn (1958); Rider (1978); Beck (1974); Beck (1975); McPherson (1977); Beck (1971).

${ }^{69} \cdot[1924]$ AC 958.

${ }^{70}$. Ibid. at 970 per Lord Dunedin.

71. Wedderburn (1958: 104-5).

72. Templeman J relied on, among other cases, Gray v Lewis (1873) LR 8 Ch App 1035 (where James LJ stated that 'the directors and majority [were] using their power for the purpose of doing something fraudulent against the minority, who are overwhelmed by them ...'), Menier, above n. 11 (where Mellish LJ held that 'the majority of shareholders cannot sell the assets of the company and keep the consideration, but must allow the minority to have their share of any consideration which may come to them') and Mason v Harris (1879) 11 Ch D 97 (where Jessel MR said that derivative action has to be permitted for it is not 'in the power of a majority to defraud the minority with impunity').

${ }^{73}$. North-West Transportation, above n. 8.

${ }^{74}$. Menier, above n. 11.

${ }^{75}$. Ibid.

${ }^{76}$. Davies and Worthington (2012: 593). 
77. O'Neill v Phillips [1999] 1 WLR 1092 at 1105.

78. In re Tobian Properties Ltd [2013] BCC 98 at [12].

${ }^{79}$. Ibid. at [28].

${ }^{80}$. Ibid. at [44].

${ }^{81}$. Ibid. at [21].

82. Gamlestaden Fastigheter AB v Baltic Partners Ltd [2007] Bus LR 1521.

${ }^{83}$. Davies and Worthington (2012: 624).

${ }^{84}$. For an endorsement of this view but from a US perspective, see Chander (2003) and the US cases examined therein.

${ }^{85}$. See Baker (1975); Birds (1976); Parkinson (1981); Gregory (1982); Cranston (1992).

${ }^{86}$. Table A, Art. 85 states:

Subject to the provisions of the Act, and provided that he has disclosed to the directors the nature and extent of any material interest of his, a director notwithstanding his office- (a) may be a party to, or otherwise interested in, any transaction or arrangement with the company or in which the company is otherwise interested; (b) may be a director or other officer of, or employed by, or a party to any transaction or arrangement with, or otherwise interested in, any body corporate promoted by the company or in which the company is otherwise interested; and (c) shall not, by reason of his office, be accountable to the company for any benefit which he derives from any such office or employment or from any such transaction or arrangement or from any interest in any such body corporate and no such transaction or arrangement shall be liable to be avoided on the ground of any such interest or conflict.

87. Table A, Art. 78 states:

A director of the company may be or become a director or other officer of, or otherwise interested in, any company promoted by the company or in which the company may be interested as shareholder or otherwise, and no such director shall be accountable to the company for any remuneration or other benefits received by him as a director or officer of, or from his interest in, such other company unless the company otherwise direct.

${ }^{88}$. Table A, Art. 84 states: 
(1) A director who is in any way, whether directly or indirectly, interested in a contract or proposed contract with the company shall declare the nature of his interest at a meeting of the directors in accordance with section 199 of the Act. (2) A director shall not vote in respect of any contract or arrangement in which he is interested, and if he shall do so his vote shall not be counted, nor shall he be counted in the quorum present at the meeting... (3) A director may hold any other office or place of profit under the company (other than the office of auditor) in conjunction with his office of director for such period and on such terms (as to remuneration and otherwise) as the directors may determine...

${ }^{89}$. Hannigan (2009: paras. 11-72).

${ }^{90} .[1988]$ BCLC 104.

${ }^{91}$. [2003] EWCA Civ 1044.

${ }^{92}$. Ibid. at [108] per Lord Justice Mummery who delivered the judgment of the court.

${ }^{93}$. Ibid. at [109].

${ }^{94}$. Davies and Worthington (2012: 629).

95. Birds (2011: 688).

${ }^{96}$. Conaglen (2011: 62).

${ }^{97}$. Frankel (1995: 1237).

${ }^{98}$. Eisenberg (1995: 249-50).

${ }^{99}$. Company Law Amendment Committee (1926: para. 46).

${ }^{100}$. Coffee (1989: 1667-1668); Coffee (1988: 944-948).

101. [2007] BCC 717.

${ }^{102}$. Ibid. at [299] and [300].

${ }^{103}$. Ibid. at [303].

${ }^{104}$. North-West Transportation, above n. 8; see also Pender v Lushington (1877) 6 Ch D 70 at 75. 
105. This is subject to the proviso that members have to act bona fide for the benefit of the company as a whole when they alter the articles.

${ }^{106}$. Wilkinson, above n. 101 at [304].

${ }^{107}$. Allen, above n. 15 .

108. Ibid.

${ }^{109}$. Ibid. at 671.

${ }^{110}$. Brown, above n. 15.

${ }^{111}$. Ibid. at 295-296 per Astbury J.

${ }^{112}$. [1951] Ch 286.

${ }^{113}$. Ibid. at 291 per Evershed MR.

${ }^{114}$. Nolan and Conaglen (2010: 329).

${ }^{115}$. Ibid at 328 and 331.

${ }^{116}$. Ibid. at 328-329.

${ }^{117}$. Brown, above n. 15.

${ }^{118}$. [1920] 1 Ch 154 (CA).

${ }^{119}$. [1927] 2 KB 9 (CA).

${ }^{120}$. Davies and Worthington (2012: 697).

${ }^{121}$. Euro Brokers Holdings Ltd v Monecor (London) Ltd [2003] 1 BCLC 506 (CA).

${ }^{122}$. Nguli v McCann (1953) 90 CLR 425; Winthrop Investments Ltd v Winns (1975) 2 NSWLR 666; Residues Treatment and Trading Co Ltd v Southern Resources Ltd (No 4) (1988) 51 SASR 196. See also Boros (1995: 200 et seq.)

${ }^{123}$. D Gregory (2009: 315); Mills (1959). 


\section{References}

Ayres I and Gertner R (1989) Filling gaps in incomplete contracts: an economic theory of default rules. Yale Law Journal 99: 87.

Baker CD (1975) Disclosure of directors' interests in contracts. Journal of Business Law: 181

Beck SM (1971) The saga of Peso Silver Mines: corporate opportunities reconsidered. Canadian Bar Review 49: 80.

Beck SM (1974) The shareholders derivative action. Canadian Bar Review 52: 159.

Beck SM (1975) The quickening of the fiduciary obligation. Canadian Bar Review 53: 771.

Berle A Jr (1958) Control in corporate law. Columbia Law Review 58: 1212.

Birds J (1976) The permissible scope of articles excluding the duties of company directors. Modern Law Review 39(4): 394.

Birds J et al. (2011) Boyle \& Birds' Company Law. $8^{\text {th }}$ ed. Bristol: Jordan Publishing.

Boros E (1995) Minority Shareholders' Remedies. Oxford: Clarendon Press.

Butler HN and Ribstein LE (1990) Opting out of fiduciary duties: a response to the anti-contractarians. Washington Law Review 65: 1.

Chander A (2003) Minorities, shareholder and otherwise. Yale Law Journal 113: 119.

Cheffins B (1991) Law and economics and morality: contracting out of corporate law fiduciary duties. Canadian Business Law Journal 19: 28.

Cranston R (1992) Limiting directors' liability: ratification, exemption and indemnification. Journal of Business Law: 197.

Coffee JC Jr (1988). No exit?: opting out, the contractual theory of the corporation, and the special case of remedies. Brooklyn Law Review: 919. 
Coffee JC Jr (1989) The mandatory/enabling balance in corporate law: an essay on the judicial role. Columbia Law Review 89: 1618 .

Company Law Amendment Committee (1925-26) Report. Cmd 2567. Great Britain: Parliament.

Conaglen M (2011) Fiduciary Loyalty: Protecting the Due Performance of Non-Fiduciary Duties. $1^{\text {st }}$ ed. Oxford: Hart.

Conaglen M (2013) Fiduciary duties and voluntary undertakings. Journal of Equity 7: 105.

Davies PL and Worthington S (2012) Principles of Modern Company Law. $9^{\text {th }}$ ed. London: Sweet \& Maxwell.

DeMott DA (1988) Beyond metaphor: an analysis of fiduciary obligation. Duke Law Journal: 879.

Duggan A (2010) Contracts, fiduciaries and the primacy of the deal. In: Bant E and Harding M (eds) Exploring Private Law. Cambridge: Cambridge University Press, pp.275-297.

Easterbrook FH and Fischel DR (1993) Contract and fiduciary duty. Journal of Law and Economics: 425.

Edelman J (2010) When do fiduciary duties arise? Law Quarterly Review 126: 302.

Edelman J (2013) The importance of the fiduciary undertaking. Journal of Equity 7: 128.

Edelman J (2010) Four fiduciary puzzles. In Bant E and Harding M (eds) Exploring Private Law. Cambridge: Cambridge University Press, pp.298-318.

Eisenberg MA (1995) The limits of cognition and the limits of contract. Stanford Law Review 47: 211.

Finn PD (1989A) Contract and the fiduciary principle. University of New South Wales Law Journal 12: 76.

Finn PD (1989B) The fiduciary principle. In: Youdan TG (ed) Equity, Fiduciaries and Trusts. Toronto: Carswell, pp.156.

FitzGibbon S (1999) Fiduciary relationships are not contracts. Marquette Law Review 82: 303.

Flannigan R (2014) Shareholder fiduciary accountability. Journal of Business Law: 1.

Frankel T (1995) Fiduciary duties as default rules. Oregon Law Review 74: 1209.

Frankel T (2011) Fiduciary Law. New York: Oxford University Press. 
Hannigan B (2000) Limitations on a shareholder's right to vote: effective ratification revisited. Journal of Business Law: 493.

Hannigan B (2009) Company Law. $2^{\text {nd }}$ ed. Oxford: Oxford University Press.

Hirt HC (2004) Ratification of breaches of directors' duties: the implications of the reform proposal regarding the availability of derivative actions. Company Lawyer 24: 197.

Gregory R (1982) The scope of the Companies Act 1948, section 205. Law Quarterly Review $98: 413$

Gregory D (2009) Grand theory. In: Gregory D et al. (eds) The Dictionary of Human Geography. $5^{\text {th }}$ ed. London: Wiley.

Koh P (2005) Directors' fiduciary duties: unthreading the joints of shareholder ratification. Journal of Corporate Law Studies 5: 363.

La Porta R et al. (2000) Investor protection and corporate governance. Journal of Financial Economics 58: 3.

La Porta R et al. (2008) The economic consequences of legal origins. Journal of Economic Literature 46: 285.

Langbein JH (2004) Mandatory rules in the law of trusts. Northwestern University Law Review 98: 1105.

Leslie MB (2005) Trusting trustees: fiduciary duties and the limits of default rules. Georgetown Law Journal 94: 67.

McPherson BH (1977) Duties of directors and the powers of shareholders. Australian Law Journal 51: 460.

Mills CW (1959) The Sociological Imagination. Oxford: Oxford University Press.

Morse G et al. (eds) (2007) Palmer's Company Law: Annotated Guide to the Companies Act 2006. London: Sweet \& Maxwell.

Mortimore S (ed) (2009) Company Directors: Duties, Liabilities, and Remedies. Oxford: Oxford University Press.

Nolan R and Conaglen M (2010) Good faith: what does it mean for fiduciaries, and what does it tell us about them. In: Bant E and Harding M (eds) Exploring Private Law. Cambridge: Cambridge University Press, pp.319-342.

Parkinson J (1981) The modification of directors' duties. Journal of Business Law: 335.

Partridge JRC (1981) Ratification and the release of directors from personal liability. Cambridge Law Journal 46(1): 122. 
Payne J (1999) A re-examination of ratification. Cambridge Law Journal 58(3): 604.

Rider B (1978) Amiable lunatics and the rule in Foss v Harbottle. Cambridge Law Journal 37(2): 270.

Riley CA (2014) Derivative claims and ratification: time to ditch some baggage. Legal Studies (34): 582.

Rotman LI (2005) Fiduciary Law. Toronto: Thomson/Carswell.

Sealy L and Worthington S (2010) Cases and Materials in Company Law. $9^{\text {th }}$ ed. Oxford: Oxford University Press.

Smith L (2012) North-West Transportation Co Ltd v Beatty (1887). In: Mitchell C and Mitchell P (eds) Landmark Cases in Equity. Oxford: Hart, pp.393-422.

Smith L (2013) Deterrence, prophylaxis and punishment in fiduciary obligations. Journal of Equity 7: 87.

Wedderburn KW (1981) Derivative action and Foss v Harbottle. Modern Law Review 44: 201.

Wedderburn KW (1957) Shareholders' rights and the rule in Foss v Harbottle. Cambridge Law Journal 15(2): 194.

Wedderburn KW (1958) Shareholders' rights and the rule in Foss v Harbottle. Cambridge Law Journal 16: 93.

Whincop M (1997) Of fault and default: contractarianism as a theory of Anglo-Australian corporate law. Melbourne University Law Review 21: 187.

Worthington S (2000) Remedying and ratifying directors' breaches. Law Quarterly Review 116: 638. 